\title{
SCANDIAN IXIOLITE FROM MOZAMBIQUE AND MADAGASCAR
}

\author{
Oleg v. Knorring *, Th. G. Sahama ** and Martti Lehtinen ** \\ * Dept. of Geology, Leeds - University, U. K. \\ ** Dept. of Geology, University of Helsinki, Finland
}

\begin{abstract}
Rounded nodules of ixiolite, exceptionally rich in scandium, are found in some granite pegmatites of Zambezia (Mozambique) and Madagascar. The ixiolite from three localities was chemically analyzed. X-ray data are given.
\end{abstract}

It is a well-known fact that pegmatitic scandium will be enriched preferably in the niobiumtantalum minerals of a pegmatite body. Specific scandium minerals such as thortveitite (befanamite) are exceedingly rare.

Probably the highest scandium content in a mineral identified as columbite by single crystal $\mathrm{X}$-ray methods was that reported by Haapala et. al. (1967). This columbite which contains $0.90 \% \mathrm{Sc}_{2} \mathrm{O}_{3}$ comes from the Haapaluoma pegmatite in Finland and exhibits a very disordered structural state.

More scandium-rich niobium-tantalum minerals are known from the pegmatites of the district of Zambezia, Mozambique, and from those of north and central Madagascar. An unusual 'columbite-tantalite' with $6.00 \% \quad \mathrm{Sc}_{2} \mathrm{O}_{3}$ was reported by v. Knorring (1965) from the Muiane pegmatite mine in Zambezia. The mineral shows an X-ray powder pattern not significantly different from that of a normal columbite-tantalite. In a 'columbite' from the pegmatites of north
Madagascar a content of $6.1 \% \mathrm{Sc}_{2} \mathrm{O}_{3}$ was found by Phan et. al. (1967). This mineral also showed an X-ray pattern similar to that of columbite. No single crystal X-ray work was done on either of the two minerals. Both the Mozambique and Madagascar minerals contain appreciable amounts of tin and titanium.

On a visit to the Muiane mine in 1966 the second author was able to collect more material of the scandium-rich Zambezia mineral from the dumps of the Mine's sorting factory. The mineral, said to come from the Naquissupa pegmatite in the neighborhood, looked similar to that studied by v. Knorring (op. cit.). During a visit to Madagascar in 1967, the first two authors were given a number of small pieces of the scandium-rich Madagascar mineral from the pegmatites of the Antsirabe area and Betanimena respectively.

Because the high scandium contents reported for these niobium-tantalum minerals are unique, the materials collected were subjected to labora- 


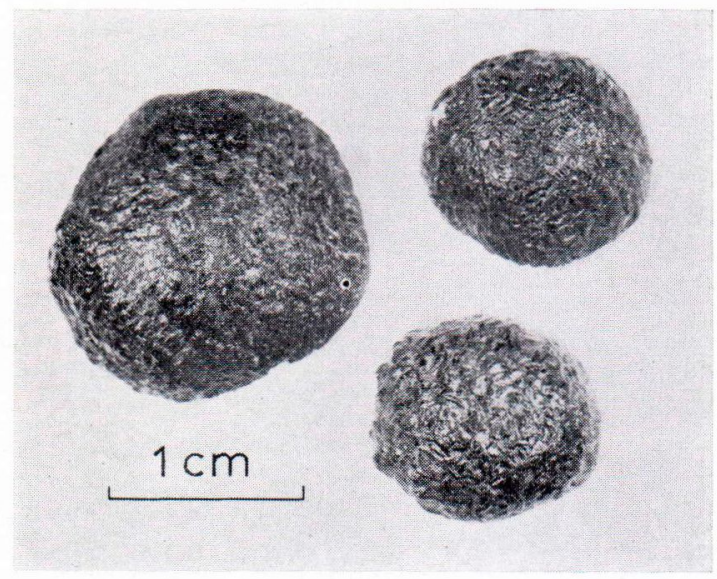

B

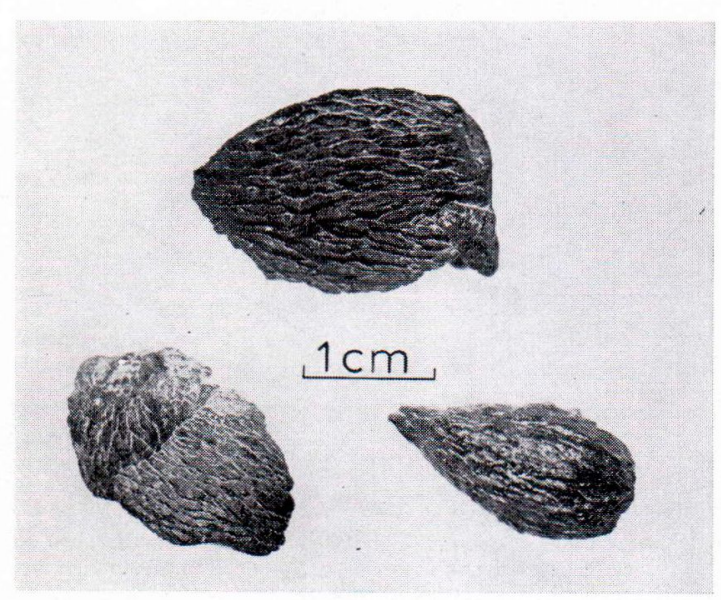

A

Fig. 1. Scandian ixiolite nodules. A. Naquissupa, Zambezia, Mozambique. B. Antsirabe area, Madagascar.

tory examination. It was found that the minerals from both Mozambique and Madagascar represent ixiolite and not columbite. The detailed results of the study will be reported in this paper.

The scandian ixiolites from Mozambique and Madagascar occur as rounded nodules usually with a flat bottom suggesting that the nodule grew on the wall of an open wug. More rarely the nodule exhibits a drop-like or irregular shape.
The nodule consists of a rosette of poorly developed crystals which are tabular parallel to the $b c$-plane. The single crystals, usually more or less curved and displaying a mosaic texture, range up to $1 \mathrm{~mm}$ in length, in a few instances to even more. The rosettes available for study are mostly $1-2 \mathrm{~cm}$ in size, but range up to ca. $3 \mathrm{~cm}$. Fig. 1 illustrates a few nodules from Naquissupa and from the Antsirabe area.

The nodules are opaque. In reflected light under the microscope no other minerals can be seen except quartz, which is mainly on the marginal parts and on the surface of the nodule. The ixiolite is relatively weakly birefringent. The grains inside the nodule are anhedral. Some nodules also contain slightly brownish monazite detectable under the binocular microscope.

The X-ray powder patterns (Philips Norelco, filtered $\mathrm{Cu}$ radiation, Si Standard) of the Naquissupa, Antisrabe area and Betanimena ixiolites agree with that of the Skogböle ixiolite reproduced by Nickel et al. (1963). In this paper the setting proposed by Laves et al. (1963) is adopted. The unit cell dimensions calculated from the powder patterns are summarized in Table 1.

TABLE 1

Unit cell dimensions of scandian ixiolite calculated from the powder pattern

\begin{tabular}{l|l|l|l}
\hline & \multicolumn{1}{|c|}{$\begin{array}{c}\text { Naquissupa, } \\
\text { Mozambique }\end{array}$} & \multicolumn{1}{|c}{$\begin{array}{c}\text { Antsirabe area, } \\
\text { Madagascar }\end{array}$} & \multicolumn{1}{|c}{$\begin{array}{c}\text { Betanimena, } \\
\text { Madagascar }\end{array}$} \\
\hline & \begin{tabular}{l|l}
$4.725 \pm 0.005 \AA$ \\
$a_{o}$
\end{tabular} & $4.741 \pm 0.005 \AA$ & $4.702 \pm 0.010 \AA$ \\
$b_{o}$ & 5.696 & 5.722 & 5.668 \\
$c_{0}$ & 5.101 & 5.123 & 5.091 \\
$V$ & $137.3 \AA^{3}$ & $139.0 \AA^{3}$ & $135.7 \AA^{3}$
\end{tabular}

A series of single crystal precession photographs of the Naquissupa, Antsirabe area and Betanimena ixiolites resemble each other and reveal the orthorhombic space group $P b c n$. No traces of additional reflections were found to indicate the presence of a columbite superstructure.

New data for the chemical composition of the scandian ixiolite from Mozambique and Mada- 


\section{TABLE 2}

Chemical composition of scandian ixiolite. New chemical analyses by Oleg v. Knorring

\begin{tabular}{|c|c|c|c|}
\hline & $\begin{array}{l}\text { Naquissupa, } \\
\text { Mozambique }\end{array}$ & $\begin{array}{c}\text { Antsirabe } \\
\text { area, } \\
\text { Madagascar }\end{array}$ & $\begin{array}{l}\text { Betanimena, } \\
\text { Madagascar }\end{array}$ \\
\hline $\mathrm{Ta}_{2} \mathrm{O}_{5} \ldots \ldots$ & $38.68 \%$ & $5.82 \%$ & $45.02 \%$ \\
\hline $\mathrm{Nb}_{2} \mathrm{O}_{5} \quad \ldots \ldots$ & 24.74 & 63.28 & 21.77 \\
\hline $\mathrm{TiO}_{2} \ldots \ldots$ & 9.32 & 6.54 & 8.23 \\
\hline $\mathrm{SnO}_{2} \ldots \ldots$ & 6.30 & 0.20 & 3.08 \\
\hline $\mathrm{Fe}_{2} \mathrm{O}_{3} \ldots \ldots$ & 5.65 & 1.32 & 8.29 \\
\hline $\mathrm{FeO} \ldots \ldots \ldots$ & 6.16 & 6.84 & 5.77 \\
\hline $\mathrm{MnO} \ldots \ldots$ & 1.76 & 9.65 & 1.51 \\
\hline $\mathrm{Sc}_{2} \mathrm{O}_{3} \ldots \ldots$ & 7.50 & 2.10 & 5.10 \\
\hline $\mathrm{RE}_{2} \mathrm{O}_{3} \ldots \ldots$ & none & $\left.2.12^{1}\right)$ & none \\
\hline Insoluble ... & 0.10 & 0.12 & 0.08 \\
\hline Total & 100.21 & $\left.99.49^{2}\right)$ & 98.85 \\
\hline
\end{tabular}

Unit cell content based on $\mathrm{O}=8$

\begin{tabular}{|c|c|c|c|}
\hline $\mathrm{Ta} \ldots \ldots \ldots$ & 0.85 & 0.12 & 1.06 \\
\hline $\mathrm{Nb} \ldots \ldots \ldots$ & 1.01 & 2.18 & 0.85 \\
\hline $\mathrm{Ti} \ldots \ldots \ldots$ & 0.56 & 0.37 & 0.54 \\
\hline $\mathrm{Sn} \ldots \ldots \ldots$ & 0.20 & 0.01 & 0.11 \\
\hline $\mathrm{Fe}^{3+} \ldots$ & 0.34 & 0.08 & 0.54 \\
\hline $\mathrm{Fe}^{2+} \ldots \ldots$ & 0.41 & 0.44 & 0.42 \\
\hline $\operatorname{Mn} \ldots \ldots \ldots$ & 0.12 & 0.62 & 0.11 \\
\hline Sc $\ldots \ldots \ldots$ & 0.53 & 0.14 & 0.39 \\
\hline RE $\ldots \ldots \ldots$ & - & 0.08 & - \\
\hline Total & 4. 02 & 4.04 & 4. 02 \\
\hline
\end{tabular}

1) Yttrium earths (optical spectroscopy).

2) Including: $\mathrm{PbO} 0.07, \mathrm{UO}_{2} 0.71, \mathrm{H}_{2} \mathrm{O}+0.67, \mathrm{H}_{2} \mathrm{O}-$ 0.05 . gascar are summarized in Table 2. The composition varies considerably, yet remains close to the general ixiolite formula $\mathrm{M}_{4} \mathrm{O}_{8}$ where $\mathrm{M}$ denotes the sum of the cations.

\section{REFERENCES}

Haapala, Ilmari, Sirvola, JaAkko and Löfgrén, Arvo (1967) On the Haapaluoma Sc-bearing columbite and its inclusions. C. R. Soc. géol. Finlande, No. 39, p. 95.

v. Knorring, Oleg (1965) Niobium-tantalum minerals. 9th Ann. Rept. Res. Inst. African Geol. Univ. Leeds, p. 43.

Laves, F., Bayer, G. und Panagos, A. (1963) Strukturelle Beziehungen zwischen den Typen $\alpha-\mathrm{PbO}_{2}, \mathrm{FeWO}_{4}$ (Wolframit) und $\mathrm{FeNb}_{2} \mathrm{O}_{6}$ (Columbit), und über die Polymorphie des $\mathrm{FeNbO}_{4}$. Min Petr. Mitt., Bd. 43, S. 217.

Nickel, E. H., Rowland, J. F. and McAdam, R. C. (1963) Ixiolite - a columbite substructure. Amer. Miner., vol. 48, p. 961.

Phan, K. D., Foissy, B., Kerjean, M., Moatti, J. et Schiltz., J. C. (1967) Le scandium dans les minéraux et les roches encaissantes de certaines pegmatites malgaches. Bull. du B. R. G. M., No. 3, p. 77.

Manuscript received, August 26, 1968. 